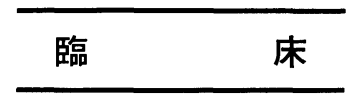

\title{
脊髄小脳変性症における
}

\section{visual suppression test そついて}

\author{
水野 正浩・山根 雅昭* ·小山内龍一*
}

\section{Visual Suppression Test in Spinocerebellar Degenerations}

\author{
Masahiro Mizuno \\ (University of Tokyo) \\ Masaaki Yamane and Ryuichi Osanai \\ (Tokyo Metropolitan Neurological Hospital)
}

Visual suppression of caloric nystagmus was studied in 86 consecutive patients with spinocerebellar degenerations.

In 16 of the 86 cases caloric nystagmus was normally suppressed by visual fixation, while in 41 it was not suppressed and in 19 it was even enhanced by visual fixation. In 10, the influence of visual fixation on caloric nystagmus could not be evaluated because of absence of caloric nystagmus or disturbance of the quick phase of nystagmus.

Patients with hereditory and/or chronic illness had a higher incidence and severer degree of disturbance of visual suppression of caloric nystagmus. The correlation between the duration of illness and the extent of visual suppression was confirmed statistically. There was no correlation, however, between the age of onset and the extent of visual suppression.

Key words: SCD, visual suppression, caloric nystagmus

はじめに

竹森らによって提唱された visual suppression test は，前庭動眼反射に対する中枢性制 御機能の測定を利用した中枢神経機能（小脳脳 幹さらには大脳をむ含む）の検査法であり, 神 経耳科学的検查法の一つとして今日広く普及し つつある 20 25).

一力, 春髄小脳変性症（以下, 脊小変之略
す）は脊䯣，小脳，脳幹に広範な変性を来す原 因不明の進行性病変であり, 従来加ら神経耳科 学の対象とされてきた。著者らも本疾患の神経 耳科学的所見について既に発表してきたが ${ }^{16)}$, 本報告では特に visual suppression test に 関して検討を加えたのでその結果を報告する.

\section{対象と方法}

対象とした症例は脊小変86例である（表 1 ).

東京大学医学部耳鼻咽喉科学教室（主任：野村恭也教授）

*東京都立神経病院神経耳科 
その内訳は男性 40 例，女性46例であった，年齢 は検査時または最終検査時（再検例）のものを 示すが, 15歳から79歳, 平均49.0歳であった. 病歴から判定した初発年歯は 5 歳から76歳で, 平均初発年秢は42.1歳であった。初発から検査 または最終検查（再検例）までの経過期間は， 4 力月から 42 年, 平均 7.5 年であった。 これら 86例のうち, 遺伝傾向を示すものは22例, 遺伝 傾向のないもの53例であった。病型は Greenfield の分類に従えば, 小脳型 9 , 脊䯣小脳型 69, 脊䯣型 4 , その他 4 であり, 大部分は脊髄 小脳型に属していた.

これらの86例について神経耳科学的検査とし て聴力検查, 体平衡機能検査, 眼振検査, 眼球 運動機能検查, 温度眼振検査と visual suppression test を行った。な扔16例については 1 年以上の期間を隔てて 2 回以上の検査を行っ たが，結果は最終検査時のものを用いた。

visual suppression test は竹森の方法 ${ }^{22}$ に 従って, ENG 記録下に行い，冷水刺激による 温度眼振の暗所開眼時之明所固視時（天井 $2 \mathrm{~m}$ の視標）の緩徐相速度を比較して visual suppression（v.s.）を算定した. v.s. が30\%を 越えるものを正常，30\%から0\%を減少ないし 消失, 明所固視時に眼振がむしろ増強するもの （一X\%） を明所眼振增強とした。 以下本文に おいては，v.s.の減少ないし消失型と，明所 眼振増強型を v.s. の異常とした。ささら一部 の症例においては, 温度眼振反応の高度低下 や, 眼振急速相の障害のため v.s. の判定が不 可能であった.

今回の報告ではこれらの visual suppression test の結果と臨床像との関連について検 討した。他の神経耳科学的検査結果との関連に ついては稿を改めて報告する予定である.

\section{結果}

visual suppression test は86症例全例に施 行したが，その結果は正常16, v.s. の減少な いし消失 41 , 明所眼振増強19であった。なお判 定不能例は10例であった。温度眼振消失例 8 例
と急速相障害12例が認められたが，乙れらのう ちの多くはv.s.の判定が不能であった．再検例 においては, 最終検査成績について検討した.

以上に述べた 86 例についての visual suppression test の成績を臨床像との関連につい て検討した結果を以下に述べる。

表 2 は初発時の年齢と v.s. との関係を示す が, 初発年歯 20 歳未満 9 例, 20 歳から 35 歳 20 例, 36 歳以上 57 例の 3 群に分けて検討した。初 発年齢により当然病型が異なると考えられる が，v.s. の異常は 3 群之も 68～78\%で大差は ない．20歳未満の若年発症者には判定不能例は みられず，20歳以上で発症した群に判定不能例 が13\%みられた。

表 3 は遺伝傾向の有無と v.s. との関係を示 したものであるが, v.s. の異常は遺伝傾向の ある群では33例中22例67\%，遺伝傾向のない群 では53例中 39 例74\% と大差はみられなかった。

しかし v.s. の異常の内訳をみる之，遺伝傾向 のない群では v.s. の減少ないし消失が53例中 31 例 $58 \%$ 之压倒的に多く, 明所眼振増強は 8 例 15\%と少ない．乙れに対して遺伝傾向のある群 では, v.s.の減少ないし消失は 33 例中 10 例 30 $\%$ ，明所眼振増強は11例 $33 \%$ とほぼ同数であっ た。なお，判定不能例は遺伝傾向のある群に33 例中 7 例 $21 \%$ と多く, 遺伝傾向のない群では53 例中 3 例 $6 \%$ 之少なかった. 判定不能の原因之 なる温度眼振反応消失は 6 例, 急速相障害は 12 例全例が遺伝傾向のある群にみられた。

表 4 は疾患の初発から検査時（再検例では最 終検查時）までの経過期間と v.s. との関係を 示したものである. 経過期間は 3 年未満, 3 年

\section{表 I 対象症例}

$$
\begin{aligned}
& \text { 対象: 脊檤小脳変性症 86例 } \\
& \text { 性: 男 } 40 \text { 女 } 46 \\
& \text { 年 秢：15 79歳 }(49.0 \pm 15.3) \\
& \text { 初発年軨：5７6歳 }(42.1 \pm 16.6) \\
& \text { 経過年数： } 4 \text { 力月 } 42 \text { 年 }(7.5 \text { 年 } \pm 6.4) \\
& \text { 遗 伝：(+)33 }(-53
\end{aligned}
$$


以上 6 年未満, 6 年以上 10 年末満, 10 年以上の 4 群に分けて検討した。 3 年未満の群では v. s. 正常の屯の屯13例中 5 例 $38 \%$ にみら，v。 s. の異常は 8 例62\%であり，その内容はすべ
て v.s. の減少ないし消失であった．経過期間 が増すと， 3 年以上 10 年末満の 2 群の v.s. の 異常は合計50例中37例74\% と増加するが，その 内容は v.s. の減少ないし消失が主であった。

表 2 初発年齢とv.s

\begin{tabular}{|c|c|c|c|c|c|c|c|}
\hline \multirow{2}{*}{ 初発年歯 } & \multirow{2}{*}{ 計 } & \multicolumn{4}{|c|}{ v. s. } & 温度反応 & 急速相 \\
\hline & & 正 常 & 減少～消失 & $\begin{array}{l}\text { 明所眼振 } \\
\text { 增 強 }\end{array}$ & 判定不能 & 消 失 & 障 害 \\
\hline 20歳末満 & 9 & 2 & 5 & 2 & 0 & 0 & 2 \\
\hline $20 \sim 35$ 歳 & 20 & 3 & 8 & 6 & 3 & 3 & 4 \\
\hline 36歳以上 & 57 & 11 & 28 & 11 & 7 & 5 & 6 \\
\hline
\end{tabular}

表 3 遺伝と v.s.

\begin{tabular}{|c|c|c|c|c|c|c|c|c|}
\hline \multirow{2}{*}{ 遺 } & \multirow{2}{*}{ 伝 } & \multirow{2}{*}{ 計 } & \multicolumn{4}{|c|}{ v. s. } & 温度反応 & 急速相 \\
\hline & & & 正 常 & 減少～消失 & $\begin{array}{l}\text { 明所眼振 } \\
\text { 増 強 }\end{array}$ & 判定不能 & 消 失 & 障 害 \\
\hline な & U & 53 & 11 & 31 & 8 & 3 & 2 & 0 \\
\hline あ & $\eta$ & 33 & 5 & 10 & 11 & 7 & 6 & 12 \\
\hline
\end{tabular}

表 4 経過年数と v.s.

\begin{tabular}{|c|c|c|c|c|c|c|c|}
\hline \multirow{2}{*}{ 経過 } & \multirow{2}{*}{ 計 } & \multicolumn{4}{|c|}{ v.s. } & 温度反応 & 急速相 \\
\hline & & 正 常 & 減少～消失 & $\begin{array}{l}\text { 明所眼振 } \\
\text { 増 強 }\end{array}$ & 判定不能 & 消 失 & 障 害 \\
\hline 3 年未満 & 13 & 5 & 8 & 0 & 0 & 0 & 0 \\
\hline 6 年未満 & 32 & 7 & 17 & 7 & 1 & 1 & 1 \\
\hline 10年末満 & 18 & 2 & 11 & 2 & 3 & 2 & 3 \\
\hline 10 年以上 & 23 & 2 & 5 & 10 & 6 & 5 & 8 \\
\hline
\end{tabular}

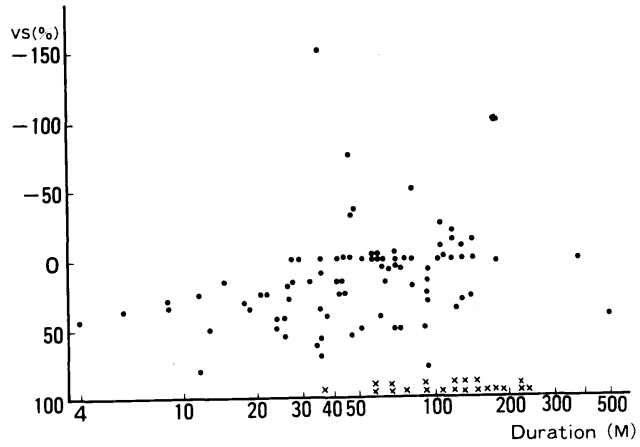

図 I 経過月数と v.s．（全症例） ( $X=$ 測定不能)

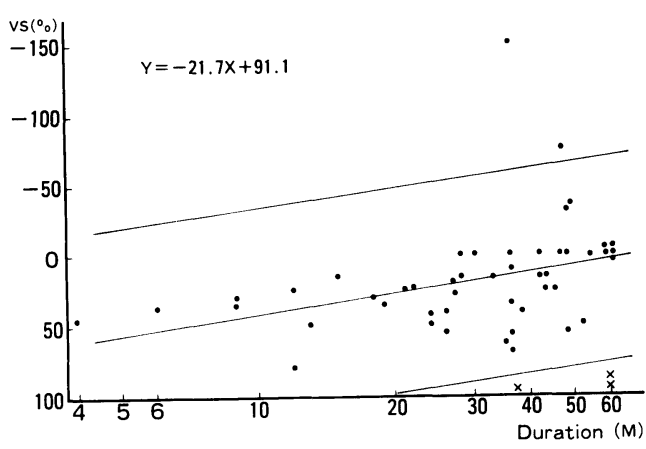

図 2 経過月数とv.s.（60力月以内例） ( $x$ 二測定不能) 
さらに 10 年以上の群では v.s. の異常は 23 例中 15 例 $65 \%$ と低下するが，内容は明所眼振増強が 10 例 $43 \%$ 之増加し, 同時に判定不能例屯 6 例 26 \%と增加するため, 結局 v.s. の正常例は 23 例 中 2 例 $9 \%$ に過ぎなくなる.

以上, 経過年数の増加とと屯に v.s. の異常 の発現率が増し，その内容も V.s. の減少ない し消失から明所眼振増強となり,さらには判定 不能例が増加する傾向がみられた。

図 1 は86症例の経時的再検查も含めた 107 回 の visual suppression test の成績之, 検査 時点での経過期間（月数の対数尺度表示）との 関係を示したものである. 経過期間の増加とと 屯に v.s. の数值が減少する傾向が認められる が，同時に60力月以上になると判定不能例が増 す.さらに明所眼振増強例之判定されたものの 一部に，正確な数值の計測が不可能なものがあ り，乙れと判定不能例とを合せた測定不能例 （×印）が増加する。

図 2 は上記の 107 回の visual suppression test のうち, 測定不能例の比較的少ない経過期 間 60 力月以内の 51 回の v.s. 值について, 図 1 と同様に図示したものである. 測定不能の 3 例 を除く 48回の v.s. 值と経過期間との相関係数 $\mathrm{R}=-0.361$ であり, $\mathrm{P}<0.05$ で有意の相関が みられた. 回帰式は $\mathrm{Y}=-21.7 \mathrm{X}+91.1 ;(\mathrm{X}$ $=\log e$ 月数）が得られた. この結果によれば, 脊小変における v.s. は発症から 1 年の時点で の約 $40 \%$ から， 5 年の時点での約 $0 \%$ と， 4 年間の経過で約 $40 \%$ 減少するととになる.

表 5 は Greenfield の分類に従った病型之 v. s. との関係を示したあのである. 脊䯣小脳 型が圧倒的に多いため，他の病型については十 分な解析が出来ないが，脊䯣小脳型では v.s. の異常の発現頻度が高く，またその内容は明所 眼振増強も多い。判定不能例 669例中 8 例 $12 \%$ と多く, その原因となる温度眼振反応消失例や 急速相の障害例も，ほとんどがこの脊䯣小脳型 に認められた。

\section{考察}

visual suppression test は, 前庭動眼反射 に対する小脳・脳幹などによる中枢性制御機構 の機能を検査する方法として近年普及しつつあ る.

中枢障害例における前庭性眼振の視临条件に よる影響については，Naito ら（1963）が温 度性眼振について，正常例では閉眼によって眼 振が増強するが, 中枢障害例では閉良によって 眼振が減少することを報告している ${ }^{17)}$.

動物実験では Fernández ら（1963）がネコ の小脳小節の破壊により回転および温度眼振の 過大, 延長と, 小節刺激による温度眼振の抑制 を報告した ${ }^{6)}$.

Hart（1967）は小脳障害例の温度眼振緩徐 相速度が，正常例とは逆に閉眼時よりも固視時 に増強するととを ENG 記録で示し，固視時 と閉眼時の温度眼振を対比して臨床応用する 方法として modified caloric test を提唱し た ${ }^{8)}$. Demanez（1968）は閉眼時之開眼時の 温度眼振の振幅と頻度の積の比を OFI（ocular fixation index) と呼んで, 中枢性病変の 鑑別診断への応用を示唆した ${ }^{4)}$. OFI という

表 5 病型とv.s.

\begin{tabular}{|c|c|c|c|c|c|c|c|}
\hline \multirow{2}{*}{ 病型 } & \multirow{2}{*}{ 計 } & \multicolumn{4}{|c|}{ v. s. } & 温度反応 & 急速相 \\
\hline & & 正 常 & 减少～消失 & $\begin{array}{l}\text { 明所眼振 } \\
\text { 増 強 }\end{array}$ & 判定不能 & 消 失 & 障 害 \\
\hline 小 脳 型 & 9 & 2 & 5 & 1 & 1 & 1 & 0 \\
\hline 脊髄小脳型 & 69 & 10 & 33 & 18 & 8 & 6 & 12 \\
\hline 脊 能有 型 & 4 & 2 & 2 & 0 & 0 & 0 & 0 \\
\hline そ の 他 & 4 & 2 & 1 & 0 & 1 & 1 & 0 \\
\hline
\end{tabular}


語は Hart $(1973)^{9)}$, Alpert $(1974)^{1)}$ む使用 したが, Alpert は温度眼振のパラメータのう ち，眼振緩徐相速度を用いることを推奖した。

一方 Coats（1970）は温度眼振緩徐相速度 が閉眼時に比べて開眼時に等しいか大なる時 に FFS (failure of fixation-suppression) 陽性と呼び, この現象は中枢性病変の $20 \%$ に認 められ，しかも主に小脳・脳幹障害例にみられ たと報告している゙2.

竹森らはサルにおける実験 ${ }^{20)} に$ 基づいて, 暗 所開眼時之固視時の温度腿振綏徐相速度の測定 から，視性の抑制率 visual suppression 求める力法を visual suppression test とし て提唱し，検討してきた ${ }^{21) ~ 25)}$.

加藤ら (1977) ${ }^{10)}$ も FFS および FVS (failure of visual suppression) について精力的 に検討し12)18)19)，コンピュータ解析も行ってい $3^{12)}$.

温度刺激以外の前庭刺激による前庭性眼振に ついての視覚の影響についても, 主に回転眼振 についての研究が臨床的になされている577.

また前庭動眼反射の視覚抑制経路についての生 理学的研究むなされつつある111311415).

なお，固視条件については遠力視よりも近見 の方が抑制率が高いという報告が多いが ${ }^{18)}$,

Collins らは異なった見解をとっている3 ${ }^{3}$.

visual suppression の障害を来す中枢性疾 患には種々のものが報告されているが，小脳 （片葉・小節），脳幹（III〜核レベルの網様 体）の病変が特に注目されてきた。 小脳・脳幹 を中心とする疾患の一つとして，脊小変に打け る v.s. についてあ多くの報告があり, 著者ら あ既に報告したが ${ }^{16)}$, 今回は特に臨床像との関 連を検討した。

86例の脊小変症例のうち, v.s. が正常なも のは16例18.6\%に過ぎず，v.s. の減少ないし 消失, あるいは明所眼振增強などの異常が60例 69.8\%に認められたととは, 疾患の部位から 考えて当然と屯思われるが，同特に v.s. の 有用性を示すむのと言えよう。しかし，10
例 $11.6 \%$ において判定不能であった点に問 題が残される. 脊小変の v.s. については竹 森ら $(1978)^{24)}$ は 17 例中 12 例 $70.6 \%$ に, 水野 $(1981)^{16)}$ は35例中 28 例 $80 \%$ に異常を認め, 加 藤ら $(1977)^{10)}$ は22例中 20 例 $90.9 \%$ FFS 陽性 であったと報告している.

v. S. の異常は，v.s. の減少・消失と明所 眼振増強とに大別され，乙の両者の病因につい ては従来からも種々の推論がなされており, v.s. の減少・消失は小脳（片葉）障害例に， また明所眼振增強は脳幹（山脳および橋網様 体）障管例に多くみられるとされる年24)25). この点㳊関して脊小変の病型と v.s. との関係 に興味が持たれる. Greenfield の分類による 本報告に拈いては脊䯣小脳型が压倒的に多く, 小脳型が少なかったため，十分な検討ができな かったが，小脳型では v.s. の減少・消失が多 いが承䯣小脳型では明所眼振増強型も多くみら れる傾向が認められたことから，明所眼振増強 の原因として脳幹の関与が示唆される.

しかし，䍜病期間（経過）の増加とと屯に v.s. の減少・消失型の比率が減り, 明所眼振 増強型が増すととは, 病変の進行拡大の他にこ の両型の間には本質的な移行があることも想定 され得ると考えられる．とのことから経過期間 と v.s. との相関を検討したが, 病型などの背 景を無視して 60 力月未満の例について検定する と, $5 \%$ 以下の危険率で有意の相関関係が認め られた. 初発後 1 年で平均約 $40 \%$ 程度の v.s. が，初発後 5 年では約 $0 \%$ となった. 経過年数 が 5 年（60力月）を過ぎると測定不能例が増す ため検定を行っていないが, 測定可能例をみる と v.s. 值はさらに減少し, 明所眼振増強例が 増加する. さらに60力月以上の群には明所眼振 增強型と判定できても, 計测不能のため测定不 能として除外した例も多く含まれている. この 事実加ら前述の v.s. の減少・消失之明所眼振 増強の二つの型には連続的移行があると思われ る.

遺伝傾向の有無と v.s. との関連についても 
既に報告があり ${ }^{1624)}$ ，経過や病型とは別個に v.s. 亿影響を与える要因の一つであることは 本報告の結果と一致する. しかし遺伝性の群に 明所眼振增強や判定不能例が多くみられる理由 は不明である. 判定不能は, 温度反応消失や急 速相障害によるが，急速相障害は遺伝性のもの にいわゆる slow eye movement を示す例が 多いととと，関連するのであろうか，一力，脊 小変において内耳障害を伴う報告もあり，温度 反応消失と関連するが，その本態は未だ解明さ れていない。

発症年齢は遺伝傾向との関連も深いと思われ るが，今回の報告においては発症年齢と v. s. の異常の頻度との関連は認められなかった。

\section{結論}

脊髄小脳変性症86例についての visual suppression test の結果を臨床像との関連におい て検討し，次の結論を得た。

i ）脊䯣小脳変性症86例の visual suppression test の結果は，正常16, v. s. の減少な いし消失 41 , 明所眼振増強 19 , 判定不能 10 であ った。なお，温度眼振消失 8 例之急速相障害 12 例が認められ，その多くはv.s. の判定が不能 であった。

ii ）発症年齢と v.s. との関連はみられなか った.

iii）遺伝傾向のあるものに明所眼振増強と測 定不能例が多かった。

iv）罹病（経過）期間の増加とともに v.s. の異常の頻度の増加がみられ，また明所眼振増 強之判定不能例が増加した。

他の神経耳科学的検查結果との関連について は稿を改めて報告する予定である.

本稿は第45回日本平衡神経科学会において報告した 内容の一部である.

症例の検查に御協力いただいた都立神経病院神経内 科の諸先生之検査技師今井智恵子氏に感謝する。

御校閲, 御指導いただいた東京大学耳鼻咽嶆科学教 室，野村恭也教授に深く感謝する.

\section{文 献}

1) Alpert JN : Failure of fixation suppression : A pathologic effect of vision on caloric nystagmus. Neurology $24: 891 \sim 896,1974$.

2 ) Coats AC: Central electronystagmographic abnormalities. Arch Otolaryngol 92:43 53, 1970 .

3 ) Collins WE, Guedry FK and Posner JB : Control of caloric nystagmus by manipulating arousal and visual fixation distance. Ann Otol 7I: 187 202, 1962.

4) Demanez JP : L'influence de la fixation oculaire sur le nystagmus postcalorique. Acta Oto-Rhino-Laryngol Belgica 22: 7, 1968.

5 ) Dichgans J, von Reutern GM and Römmelt $\mathrm{U}$ : Impaired suppression of vestibular nystagmus by fixation in cerebellar and noncerebellar patients. Arch Psychiat Nervenkr $226:$ 183 199, 1978.

6) Fernández CF and Fredrickson JM : Experimental cerebellar lesions and their effect on vestibular function. Acta Otolaryngol Suppl I92:52〜62, 1963.

7) Halmagyi GM and Gresty MA : Clinical signs of visual-vestibular interaction. $\mathrm{J} \mathrm{Ne}-$ urol Neurosurg Psychiat $42: 934 \sim 939$, 1979.

8) Hart CW: Ocular fixation and the caloric test. Laryngoscope $77: 2103 \sim 2113,1967$.

9) Hart CW: The ocular fixation index. Ann Otol $82: 848 \sim 851,1973$.

10）加藤 功, 小池吉郎, 青柳 優, 他: 開眼, 固視 による前庭性眼振への抑制効果検査の診断的意 義一Caloric pattern test について一。 日耳鼻 $80: 507 \sim 514,1977$.

11）加藤 功, 川崎 匡, 佐藤 悠：温度性眼振の光 による抑制効果における橋被蓋網様体核の役割. Equilibrium Res $39: 12 \sim 16,1980$.

12) 加藤 功, 渡辺 仁, 中村 正: 迷路性眼振に対 する視性抑制の検査. めまい（鈴木淳一，時田 喬編)．205～221頁，現代医療社，東京，1983.

13）川崎 匡, 佐藤 悠, 加藤 功：小脳片葉への視 覚系入力経路. Equilibrium Res 39: 1 6, 
1980.

14) Maekawa $K$ and Simpson JI : Climbing fiber responses evoked in vestibulocerebellum of rabbit from visual system. J Neurophysiol $36: 649 \sim 666,1973$.

15) Maekawa $K$ and Takeda $T$ : Mossy fiber responses evoked in the cerebellar flocculus of rabbits by stimulation of the optic pathway. Brain Research $98: 590 \sim 595,1975$.

16）水野正浩：春娟道小脑変性症における神経耳科学的 所見. 耳鼻臨床 $74: 68 \sim 88,1981$.

17) Naito $T$, Tatsumi $T$, Matsunaga $T$, et al : The effect of eye-closure upon nystagmus. Acta Otolaryngol Suppl 179:72 85, 1963.

18）中村 正, 加藤 功, 木村 洋, 他: 温度性眼振 に対する固視による抑制率一正常例と異常例につ いて一. Equilibrium Res 39: $7 \sim 11,1980$.

19）佐藤 悠, 川崎 匡, 加藤 功, 他: 温度性眼振 の固視抑制と眼球運動機能について. 日耳鼻 81 : 106 112, 1978.

20) Takemori S and Cohen B: Loss of visual suppression of vestibular nystagmus after flocculus lesions. Brain Research $72: 213$ $\sim 224,1974$.

21）竹森節子：前庭動眼反射と前庭小脳の干渉. 耳鼻 臨床 $68: 1327 \sim 1332,1975$.

22）竹森節子：固視機能検查法としての Visual Suppression Test. 耳鼻臨床 $69: 1049 \sim 1056$, 1976.

23) Takemori $\mathrm{S}:$ Visual suppression test. Ann Otol $86: 80 \sim 85,1977$.

24）竹森節子, 須田南美, 別府宏图：Visual Suppression Test による小脳, 脳幹障害の鑑別に ついて. Equilibrium Res $37: 88 \sim 92,1978$.

25）竹森節子：Visual suppression の消失一温度眼 振の固視下の増強の機序について一. Equilibrium Res 4I: 190 191, 1982.

$$
\left(\begin{array}{l}
\text { 原稿採択 : 昭和 } 62 \text { 年 } 4 \text { 月 } 27 \text { 日 } \\
\text { 別刷請求先 : 水野正浩 } \\
\text { T113 東京都文京区本郷 } 7-3-1 \\
\text { 東京大学医学部耳鼻咽喉科学教室 }
\end{array}\right.
$$

